Review article

\title{
The issue of documenting pressure ulcers: literary review
}

\author{
Katarína Kačalová ${ }^{1,2}{ }^{*}$, Katarína Žiaková ${ }^{1}$ \\ ${ }^{1}$ Comenius University in Bratislava, Jessenius Faculty of Medicine in Martin, Department of Nursing, Martin, Slovak Republic \\ ${ }^{2}$ General Health Insurance Company, a. s., Health and Review Methodology Department, Bratislava, Slovak Republic
}

\begin{abstract}
Objective: To find, analyze and compare clinical recommended practices, national recommendations, guidelines, nursing standards and assessment tools with a focus on documenting pressure ulcers.

Methodology: The selection of relevant sources was carried out in 2018 using search services and sources in electronic databases (Medline, ProQuest, PubMed), book publications, from professional societies, and professional journals. Out of 139 sources, 38 sources were selected and processed in three phases based on the ranking and exclusion criteria.

Results: By analyzing and comparing clinically recommended procedures, national recommendations, guidelines, nursing standards and assessment tools to document pressure ulcers, we have found that the most frequently reiterated requirement for pressure ulcers is: degree of pressure ulcer, its location, size, base, exudate and surroundings. The most observed items that tell us about documenting of the pressure ulcer healing process are found in the NPUAP, EPUAP, PPPIA consensus (GRADE), HSE, AAWC, and RNAO guidelines.

Conclusions: Pressure ulcer documenting is a problem addressed within national and international recommendations or guidelines. Their analysis and comparison revealed several worldwide unified documentation requirements, which are essential to multidisciplinary collaboration and decision-making on further treatment.
\end{abstract}

Keywords: Assessing and documenting pressure ulcers; Assessment tools for pressure ulcers classification; National guidelines for documenting pressure ulcers

\section{Introduction}

Consistent and timely recording of nursing care for pressure ulcers supports communication, continuity, decision-making on further treatment, and improves patient safety. Documenting of pressure ulcers is a part of the directives, standards or recommended practices in the Slovak Republic and abroad regarding the classification of pressure ulcers and the assessment of their healing during treatment. In the practice of documenting, it is recommended to record care as soon as it is provided, identify risks or problems that have arisen, fill in all records accurately and without any falsification, record your own notes in the documentation without unnecessary abbreviations (with a precise date and time), keep the documentation safe, and process and store research data and results accordingly (Nursing and Midwifery Council, 2015). Foreign studies point to a lack of nursing care tracking in line with holistic approach, legislation and professional standards (Dehghan et al., 2015; Gunningberg et al., 2008; Høgsnes et al., 2016; Vainiomäki et al., 2008; Wang et al., 2011). In Slovakia, the proper management of nursing documentation is the legislative and professional requirement of nursing practice, which is also the basis for the creation of contracts between health care providers and the health insurance company. Insufficient or absent recordings of pressure ulcer assessments as well as discrepancies between data recorded in the nursing documentation and data recorded in the health insurance information system indicate not only a reduced quality of documentation management but also suspect illegal activity. It is therefore necessary to know the correct and recommended way of assessing pressure ulcers and recording them in the documentation. An initial assessment associated with the inclusion of a pressure ulcer in a particular classification grade is decisive in determining treatment and treatment procedures. The guideline for the inclusion of pressure ulcers in the relevant classification stage is the National Pressure Ulcer Advisory Panel, and the European Pressure Injury Alliance (NPUAP, EPUAP, PPPIA, 2014). Individual countries create their own standards, guidelines or best practices, which relate not only to the inclusion of pressure ulcers into the classification stage, but also to the follow-up of the pressure ulcer healing process and its documentation. They are: Wounds Australia (AWMA, 2016), the European Wound Management Association (EWMA, 2019), which, together with the European Pressure ulcer advisory panel (EPUAP, 2014) co-operates with the OECD (2019) in the field of pressure ulcer management at European level, National Institute for Health and Care Excellence (NICE, 2014), Agency for Healthcare Research and Quality (AHRQ, 2017), Association for Advance of Wound Care (AAWC, 2010), Health Ser-

\footnotetext{
* Author for correspondence: Katarína Kačalová, General Health Insurance Company, a. s., Directorate General, Health and Review Methodology Department, Panónska cesta 2, 85104 Bratislava, Slovak Republic; e-mail: katarina.kacalova@vszp.sk http://doi.org/10.32725/kont.2019.034

Submitted: 2019-01-04 • Accepted: 2019-04-26 • Prepublished online: 2019-08-01 
vice Executive (HSE, 2018), Registered Nurses“ Association of Ontario, Canada (RNAO, 2018); Dowsett and Newton (2005), National Health Service (NHS, 2009), Methodological Recommendation of the Ministry of Health of the Czech Republic (Journal of the Ministry of Health CR, 2009), Professional Guidance of the Ministry of Health of the Slovak Republic (Journal of the Ministry of Health SR 2004a).

The aim of the study was to find, analyze and compare clinical recommended practices, national recommendations, guidelines, nursing standards, and assessment tools to document pressure ulcers.

\section{Materials and methods}

This contribution has the character of a review study. In the course of 2018, search services for the National Center for Health Information - the Slovak Medical Library (NCZI-SLK), where 67 sources from the Medline electronic database and 6 book publications were provided to search for relevant sources. In addition, publications from ProQuest, PubMed, and professional journals were included in the analysis. We used the following keywords and their combination to search: pressure ulcer treatment, pressure ulcer treatment standard, pressure ulcer care, pressure ulcer monitoring and evaluation, pressure ulcers guidelines. Out of 139 sources, 25 sources from electronic databases, 9 sources from professional societies, 2 sources from professional journals and 2 book publications were selected. The selection was made on the basis of fulfilling the inclusion criteria, including the assessment and documentation of pressure ulcers, assessment tools for pressure ulcers classification, English, Slovak and Czech, free contribution fully containing information on pressure ulcers assessment and evaluation. Eliminating criteria included the prevention of pressure ulcers, care for primary healing wounds, other language than English, Slovak, Czech, duplicates, material requiring registration and payment. The selection was made in three phases. All sources were included in the first phase and those that contained the exclusion criteria were excluded according to their content. In the second phase, resources that contained incomplete information on the assessment and evaluation of pressure ulcers were excluded. In the third phase, the resources were divided into resources related to the Guidelines / Standards / Recommended Practices for Documenting Pressure ulcers (Tables 1 and 2) and sources containing Evaluation Tools designed to classify pressure ulcers.

\section{Results}

By analyzing and comparing clinically recommended procedures, national recommendations, guidelines, nursing standards, and assessment tools to document pressure ulcers, we found that the most frequent requirement for documentary pressure is degree of pressure ulcer, location, size, base, exudate, and environment (Table 1). The most monitored items that tell us about documenting the course of pressure ulcer healing can be found in the NPUAP, EPUAP, PPPIA (2014) guidelines with consensual approach (GRADE), HSE, AAWC and RNAO (Table 2). The recommended assessment tools for inclusion of pressure ulcers in the respective classification grade are given in Table 3 .

Table 1. Guidelines / Standards / Recommended Practices for Documenting pressure ulcers

\begin{tabular}{|c|c|c|}
\hline Source & $\begin{array}{l}\text { Enrollment Requirements } \\
\text { (by stage, score, multiple factors) }\end{array}$ & Detailed description of the requirement \\
\hline \multirow{18}{*}{ NPUAP, EPUAP, PPPIA (2014) } & classification of pressure ulcers by degree & I. degree - fading hyperemia \\
\hline & & II. degree - partial loss of skin cover \\
\hline & & III. degree - total loss of skin cover \\
\hline & & IV. degree - total loss of skin cover and subcutaneous tissue \\
\hline & & without determining degree - unknown depth \\
\hline & & suspected deep tissue damage \\
\hline & location & \\
\hline & size & $\begin{array}{l}\text { writing values of length, width, and depth measured at the same } \\
\text { neutral position }\end{array}$ \\
\hline & tissue type & \\
\hline & colour & $\begin{array}{l}\text { skin temperature, skin sensitivity, changes in tissue consistency, } \\
\text { pain should be recorded in patients with dark skin and pressure } \\
\text { ulcers II.-IV. }\end{array}$ \\
\hline & condition of pressure ulcer surroundings & swelling, redness \\
\hline & edges & \\
\hline & sinuses & \\
\hline & undergrounding & recording the values after carefully probing the wound \\
\hline & tunneling & \\
\hline & exudate & writing the amount of exudate, its character (presence of pus) \\
\hline & odour & \\
\hline & pain & $\begin{array}{c}\text { scales to assess pain, nonverbal and verbal manifestations, write } \\
\text { intensity and frequency }\end{array}$ \\
\hline \multirow{5}{*}{ AWMA (2016) } & anatomic location & \\
\hline & size & length, width, depth measured from the longest/deepest part \\
\hline & undeground part & description of the range using a probe \\
\hline & area & circuit and surface notation planimetry \\
\hline & volume & writing values measured with sterile liquid or filler \\
\hline
\end{tabular}


Table 1. (Continued)

\begin{tabular}{|c|c|c|}
\hline Source & $\begin{array}{l}\text { Enrollment Requirements } \\
\text { (by stage, score, multiple factors) }\end{array}$ & Detailed description of the requirement \\
\hline \multirow{9}{*}{ AWMA (2016) } & base & $\begin{array}{l}\text { agranulation, granulation, hypergranulation epithelialization, yellow } \\
\text { tissue, necrosis/eschara, exposed }\end{array}$ \\
\hline & & bone or tendon, foreign body, fistula \\
\hline & edges & increased, cylindrical, undergrounding, coloring \\
\hline & characteristics of the surrounding skin & $\begin{array}{c}\text { notation - erythema, edema, abnormal strength, maceration, } \\
\text { drying out, dermatitis/eczema, callus, hyperkeratosis, pigmentation } \\
\text { changes, urticaria and temperature }\end{array}$ \\
\hline & exudate & type - serous, sanguinous, seropurulent, purulent, amount and odor \\
\hline & & consistency (thick, thin) \\
\hline & healing phase & $\begin{array}{c}\text { hemostasis, inflammation, reconstruction, epithelization, } \\
\text { remodeling }\end{array}$ \\
\hline & signs of inflammation or infection & $\begin{array}{c}\text { range - local infection, spread of infection, systemic infection based } \\
\text { on clinical signs and/or examinations }\end{array}$ \\
\hline & pain & $\begin{array}{l}\text { verbal and nonverbal manifestations; location, character, intensity; } \\
\text { duration; noncyclic, cyclic, chronic }\end{array}$ \\
\hline \multirow{6}{*}{ NICE (2014) } & $\begin{array}{c}\text { categorization using a classification tool (e.g. } \\
\text { International Pressure Ulcer Classification } \\
\text { System NPUAP-EPUAP) }\end{array}$ & \\
\hline & area & \\
\hline & depth & \\
\hline & undergrounding & \\
\hline & pain & \\
\hline & color, temperature, strength, skin moisture & \\
\hline \multirow{15}{*}{ AHRQ (2017) } & $\begin{array}{l}\text { description using Bates-Jensen (2001) Wound } \\
\text { Assessment Tool (BWAT) and other standard } \\
\text { treatment and intervention descriptions }\end{array}$ & \\
\hline & origin, start date & acquired in the facility, present at reception, acquired at the facility \\
\hline & location & \\
\hline & initial phase & \\
\hline & size & $\begin{array}{l}\text { length, width, and depth, writing values measured with a ruler in } \\
\text { centimeters; multiply by } \times \text { width }\end{array}$ \\
\hline & edge of pressure ulcer & $\begin{array}{c}\text { description of appearance - diffuse, snug without side surfaces, } \\
\text { not attached to deep base such as edge, cylindrical, fibrotic, } \\
\text { hyperkeratosis }\end{array}$ \\
\hline & undergrounding & $\begin{array}{l}\text { a description of the measurement by inserting a cotton tip } \\
\text { applicator under the wound edge }\end{array}$ \\
\hline & tunneling & description of direction and length \\
\hline & necrotic tissue & $\begin{array}{l}\text { description of type and quantity - e.g. white/gray, non-adherent } \\
\text { yellow tissue, loosely adherent yellow tissue, adherent soft black } \\
\text { crust, firm, adherent hard, black crust, amount measured with a } \\
\text { transparent metric guide }\end{array}$ \\
\hline & exudate & $\begin{array}{l}\text { Type and amount - e.g. serosanguinous, serous, no amount, small, } \\
\text { medium, large }\end{array}$ \\
\hline & surrounding of pressure ulcer & skin color, temperature/redness, edema and induration \\
\hline & granulating tissue & writing the range as a percentage of filling the base \\
\hline & epitelization & writing the range as a percentage of filling the base \\
\hline & pain & selection on a range of pain by rating from 0 to 10 \\
\hline & classification level & I. to IV., not classifiable, suspected deep tissue damage \\
\hline \multirow{8}{*}{ AAWC (2010) } & anatomical location & record of location by Bates-Jensen (2001) \\
\hline & size & writing length, width, depth of pressure ulcer \\
\hline & exudate & $\begin{array}{l}\text { character - sanguineous, serous, purulent, and many - none, small, } \\
\text { medium, large }\end{array}$ \\
\hline & signs of infection & $\begin{array}{c}\text { erythema, edema, odor, purulent exudate, increasing pain, } \\
\text { temperature }\end{array}$ \\
\hline & undergrounding, sinuses & \\
\hline & tunneling & \\
\hline & type and amount of tissue & $\begin{array}{c}\text { epithelialization, granulation, yellow / whitish fibrin / tissue or } \\
\text { black, brown, gray necrotic tissue }\end{array}$ \\
\hline & edges of pressure ulcer & abnormalities \\
\hline
\end{tabular}


Table 1. (Continued)

\begin{tabular}{|c|c|c|}
\hline Source & $\begin{array}{l}\text { Enrollment Requirements } \\
\text { (by stage, score, multiple factors) }\end{array}$ & Detailed description of the requirement \\
\hline \multirow{2}{*}{ AAWC (2010) } & surrounding of pressure ulcer & erythema or edema \\
\hline & pain & using of evaluation scale \\
\hline \multirow{12}{*}{ HSE (2018) } & classification by NPUAP/EPUAP & \\
\hline & location & \\
\hline & size & \\
\hline & type of tissue & \\
\hline & color & \\
\hline & surrounding & \\
\hline & edges & \\
\hline & sinuses & \\
\hline & undergrounding & \\
\hline & tunneling & \\
\hline & exudate & \\
\hline & odor & \\
\hline \multirow{10}{*}{ RNAO (2018) } & location & \\
\hline & depth/ degree & $\begin{array}{l}\text { categorization using a classification tool (for example the } \\
\text { International Pressure Ulcer Classification System NPUAP-EPUAP) }\end{array}$ \\
\hline & size & use ruler or photo \\
\hline & odor & \\
\hline & sinuses & \\
\hline & undergrounding & \\
\hline & tunneling & \\
\hline & exudate & $\begin{array}{l}\text { serous, sanguine, serosanguine, purulent, and many none, small, } \\
\text { medium, large }\end{array}$ \\
\hline & base & black, yellow, pink/red \\
\hline & $\begin{array}{l}\text { the appearance and condition of the } \\
\text { surrounding skin and the edges of the } \\
\text { pressure ulcer }\end{array}$ & \\
\hline \multirow{3}{*}{ Dowsett and Newton (2005) } & base & type, exudate, infection \\
\hline & edges & macerated, dry, undermined, cylindrical \\
\hline & surrounding & macerated, dry, excretion, hyperkeratosis, calus, eczema \\
\hline \multirow{10}{*}{ NHS (2009) } & $\begin{array}{c}\text { categorization using a classification tool (eg } \\
\text { International Pressure Ulcer Classification } \\
\text { System NPUAP-EPUAP) }\end{array}$ & $\begin{array}{l}\text { categorization using a classification tool (eg International Pressure } \\
\text { Ulcer Classification System NPUAP-EPUAP) }\end{array}$ \\
\hline & location & \\
\hline & case & \\
\hline & size & \\
\hline & the appearance of base & \\
\hline & exudate & \\
\hline & odor & \\
\hline & the condition of the surrounding skin & \\
\hline & presence of infection & \\
\hline & pain & \\
\hline \multirow{3}{*}{$\begin{array}{l}\text { Journal of the Ministry } \\
\text { of Health CR (2009) }\end{array}$} & $\begin{array}{l}\text { the degree of tissue involvement using the } \\
\text { Hibbs scale }\end{array}$ & levels 1 to 4 according to Hibbs \\
\hline & anatomical location & \\
\hline & diameter of pressure ulcer $(\mathrm{mm})$ & $\begin{array}{l}\text { writing an approximated average diameter of a constructed circular } \\
\text { pressure ulcer }\end{array}$ \\
\hline \multirow{6}{*}{$\begin{array}{l}\text { Journal of the Ministry } \\
\text { of Health SR (2004a) }\end{array}$} & pressure ulcer stage or healing phase & \\
\hline & location & \\
\hline & size of pressure ulcer & writing length, width, depth \\
\hline & colour & \\
\hline & surrounding of pressure ulcer & redness, swelling, maceration \\
\hline & skin turgor & \\
\hline
\end{tabular}




$$
\mid
$$


Table 3. Evaluation tools designed to classify pressure ulcers

\begin{tabular}{|c|c|c|}
\hline Title by & $\begin{array}{l}\text { Enrollment Requirements } \\
\text { (by stage, score, multiple factors) }\end{array}$ & Description of the recorded pressure ulcer assessment \\
\hline \multirow{6}{*}{$\begin{array}{l}\text { NPUAP, EPUAP, } \\
\text { PPPIA (2014) }\end{array}$} & degree I & fading hyperemia \\
\hline & degree II & partial loss of skin cover \\
\hline & degree III & total loss of skin cover \\
\hline & degree IV & total loss of skin cover and subcutaneous tissue \\
\hline & without determining degree & unknown depth, complete loss of tissue with a base covering \\
\hline & suspected deep tissue damage & unknown depth, violet-colored blister \\
\hline \multirow{6}{*}{ Knighton (2015) } & degree I & superficial damage (epidermis, dermis) \\
\hline & degree II & deep damage (interferes with subcutis) \\
\hline & degree III & fascia involvement \\
\hline & degree IV & muscle involvement \\
\hline & degree $\mathrm{V}$ & affecting tendons, ligaments, bones \\
\hline & degree VI & affecting large cavities \\
\hline \multirow{5}{*}{ Shea (1975) } & degree I & $\begin{array}{l}\text { disappearing redness, the area may be painful, firm, soft, and warmer or cooler than } \\
\text { adjacent tissues }\end{array}$ \\
\hline & degree II & partial loss of skin cover, manifested as a shallow open red-pink ulcer \\
\hline & degree III & $\begin{array}{l}\text { tissue loss in full thickness, subcutaneous fat may be visible, but bone, tendon or muscle } \\
\text { not visible, undergrounding presence, tunneling may be present }\end{array}$ \\
\hline & degree IV & loss of full thickness tissue with exposed bone, tendon or muscle \\
\hline & unclassified & $\begin{array}{c}\text { base covered with yellow, gray, green or brown tissue, no depth can be determined } \\
\text { without removal }\end{array}$ \\
\hline \multirow{4}{*}{ Hibbsová (2009) } & degree I & $\begin{array}{c}\text { fading redness persisting even after } 5 \text { min., after relieving the exposed area, capillary } \\
\text { blood flow within } 30 \text { min. recovers }\end{array}$ \\
\hline & stage II & partial loss of skin, blister, wet surface \\
\hline & stage III & $\begin{array}{l}\text { complete loss of skin and subcutaneous tissue, gray or black crust, deep soft tissues } \\
\text { (fascia, muscles) are intact }\end{array}$ \\
\hline & stage IV & $\begin{array}{l}\text { loss of skin with extensive damage to deep functional structures, necrosis, } \\
\text { undergrounding, penetration into adjacent cavities and joints }\end{array}$ \\
\hline \multirow{5}{*}{ Torrance (2015) } & degree I & fading erythema \\
\hline & degree II & unfading erythema \\
\hline & degree III & superficial ulceration at the subcutaneous tissue interface \\
\hline & degree IV & subcutaneous fascia ulceration \\
\hline & degree V & infectious necrosis into the subcutaneous fascia \\
\hline \multirow{5}{*}{ Daniel (2015) } & degree I & redness of the skin \\
\hline & degree II & superficial skin ulceration \\
\hline & degree III & subcutaneous fat necrosis \\
\hline & degree IV & affecting deep structures except bones \\
\hline & degree $\mathrm{V}$ & extensive necrosis with osteomyelitis, joint destruction \\
\hline \multirow{3}{*}{ Seiler (2015) } & A & pure granular wound without necroses \\
\hline & B & coated wound with residues of necroses is not infected with the surrounding \\
\hline & C & coated wound with necrosis residues, infected surrounding, signs of general sepsis \\
\hline
\end{tabular}

\section{Discussion}

When recording the degree of pressure ulcer into the documentation, the international system of classifying pressure ulcers (NPUAP, EPUAP and PPPIA) is most often recommended in line with evidence-based practice (EBP). Historically, this has been preceded by several classification systems (Black et al., 2007) developed by several authors such as: classification according to Knighton (2015), Hibbs (currently also required by the Journal of the Ministry of Health CR, 2009), Torrance (2015), Daniel (2015), Seiler (2015), Shea (1975). A systematic literature review by Stausberg and Kiefer (2009) found that up to 31 classification systems could be identified. The classification grade system is based on anatomy and the extent of damaged tissue, and cannot be reversed in documenting 
the healing process (Baharestani et al., 2009). To record the location of a pressure ulcer, guidelines (AAWC, 2010; AHRQ, 2017) recommend the BWAT assessment tool, which allows you to select a location from the offered options and label it with an " $X$ " on the body map. Incontinence-related dermatitis - Associated Dermatitis Incontinence (IAD) from pressure ulcer (Pokorná et al., 2016) is necessary to localize in areas affected by incontinence. Appropriate terminology (front, back, mediolateral or proximal distance) should be used for enrollment (Melter, 2017). Often used is image plotting of the location on the so-called map of the human body (Journal of the Ministry of Health SR, 2000). The fastest and easiest method to measure pressure ulcer size is to use a disposable paper ruler to record the length and width in $\mathrm{cm}$, giving you an indication of the size of the pressure ulcer surface. It is important where the measurements are made because they can fundamentally affect the outcome. One method is to measure the greatest length and the greatest width of the pressure ulcer. In the second method, the largest length and largest width are measured perpendicular to each other at a $90^{\circ}$ angle from head to toe (Nichols, 2015). Depth should be recorded according to the deepest portion measured sterile, using a cotton tip applicator or with plastic probes marked in $\mathrm{cm}$. A clock face is used in the description method assuming that 12 hours is from the head of the patient, who is laying in the same position during the measuring (Nichols, 2015). RNAO recommends the use of a ruler or a photograph to measure the size of the pressure ulcer, the recommendations of the Ministry of Health of the Czech Republic describe the writing of an approximated value of the diameter of the constructed circular pressure ulcer. The choice of the method of measuring and recording the size of the pressure ulcer in the documentation should remain unchanged during further review and documentation in the healing process. The base of the pressure ulcer of the NPUAP, EPUAP, PPPIA (2014) directive evaluates the degree of skin cover loss, AHRQ (2017) recommends the scaling of the epitalization and granulation tissue range as a percentage of the base filling and, in the case of necrotic tissue, the description of the type and quantity (e.g. white/gray, non-adherent yellow tissue, loosely adherent yellow tissue, adherent soft black crust, firm, adherent, hard, black eschar), RNAO recommends to distinguish the base by color (black, yellow, pink/red). According to Australian standards, it is assessed whether it is agranulation, granulation, hypergranulation epithelialization, yellow tissue wound slough, necrosis/eschar, exposed bone or tendon or fistula. It is recommended to record the amount and nature of the exudate in relation to the scoring. The EPUAP, NPUAP, PPPIA (2014) guidelines document the amount of exudate and its nature (presence of pus), similarly, AWMA requires documenting the type of exudate (serous, sanguineous, seropurulent, purulent), amount and its odor. According to AHRQ (2017), the type of exudate (e.g., sanguineous, serosanguinous, serous) is recorded, and is defined as none, small, medium, large, which is consistent with the AAWC guidelines. When documenting the pressure ulcer assessment, account must be taken of the consistency of the recorded data with a brief and concise record of all necessary information.

Assessing the pressure ulcer edges is important for the healing process that starts from the edges. AWMA recommends evaluating the edges as raised, cylindrical, undergrounding, while also highlighting their color. The AHRQ (2017) program suggests documenting the edges with a description of the appearance (diffuse, snug without side, not attached to a deeper base, such as edge, rolled, fibrotic, hyperkeratosis). Wound Asia recommends differentiating between macerated, dry, undergrounding or cylindrical edges. Most of the above guidelines and recommendations also agree on the need to document the environment of the pressure ulcer. The skin should be scored at least $4 \mathrm{~cm}$ around the wound (Melter, 2017). The AHRQ (2017) program emphasizes the need to record skin color around pressure ulcer, temperature/redness, edema, and stiffness. Similarly, the AAWC association recommends writing erythema or edema around the pressure ulcer. Canadian RNAO Association also recommends the appearance and appearance of the surrounding skin. Dowsett and Newton (2005) define a pressure ulcer environment as macerated, dry, with excoriation, hyperkeratosis, callus, eczema. The Slovak Framework Process Standard recommends that redness, swelling, and maceration in the vicinity of the pressure ulcer be recorded. In addition to the above parameters, guidelines and recommendations emphasize the need to document conditioning, tunneling, sinus, pressure ulcer volume measured with a sterile liquid, skin color, temperature/inflammation, odor, pain, and skin turgor (see Table 3).

When documenting according to the recommendations mentioned above, certain forms of individual parameter recording such as e.g. Wound Healing Continuum (WHC), which evaluates and documents the color change base, Wound Infection Continuum (WIC), recording microbial settlement and Wound Exudate Continuum (WEC) rating based on exudate volume and consistency (Gray et al., 2010), or the TIME model, which aims to relieve swelling, maintain optimal moisture removal of the biofilm with reduction of bacterial load, promote edge effect healing (Dowsett et al., 2018). Various technical and electronic pressure ulcer assessment systems are also recommended, such as e.g. Wound Healing Analyzing Tool (WHAT), which enables electronic wound analysis (W.H.A.T., 2013), or the use of working mini laptops with an electronic form software installed (ASSIDIS software) (Jarošová et al., 2012). Another method for documenting and archiving pressure ulcer data is using Visitrak (Stryja et al., 2011). In Slovakia, the documentation of pressure ulcers is based on the professional guidance of the Ministry of Health on the management of health documentation (Journal of the Ministry of Health SR, 2009), according to which the entry in the documentation should include a brief description of the performance provided and its evaluation. According to the current standard no. 85 - Nursing care for a patient with pressure ulcer in the home environment (Journal of the Ministry of Health SR, 2004a), the nurse records the assessment of the pressure ulcer according to the stage or phase of healing appearance of the surrounding skin (presence of redness, swelling and maceration), and then further records pressure ulcer location, pressure ulcer character, determines depth damage and measures the length and width of the pressure ulcer. The compliance of the record in the documentation with the valid legislation and professional recommendations is monitored by the review nurse in the framework of the inspection activity. Its job position and competencies are defined by legislation in Slovakia (Act No. 581/2004).

In the context of the above-mentioned international recommendations for the documentation of pressure ulcers, the notation should also be supplemented with an assessment of the base, exudate and pressure ulcer margins, but if these parameters are understood as "pressure ulcer character" as given in standard no. 85, the required data should be comprehensive in view of the most frequently encountered requirements for documenting pressure ulcers. However, the problem remains that the registration of the pressure ulcer assessment in the documentation in the context of the above requirements re- 
mains time-consuming and burdensome for the nurse. The availability of electronic devices and their proper use in documenting the assessment of pressure ulcers could reduce the time-consuming work of the nurse while ensuring clarity of the pressure ulcer assessment and healing process.

\section{Conclusions}

Documenting pressure ulcers is a problem addressed within national and international recommendations or guidelines. Their analysis and comparison revealed several worldwide unified documentation requirements, which are essential to multidisciplinary collaboration and decision-making on further treatment. In the initial assessment of pressure ulcers, the international pressure ulcer classification system NPUAP, EPUAP, PPPIA, which classifies pressure ulcer into four grades and two separate stages with unknown depth and suspected deep tissue damage, is most commonly recommended. It is evident from the overview of the individual guidelines/standards/recommended procedures required for entry into the documentation (Table 2) that the pressure ulcer documentation should, in particular, include: determination of location, size, base, exudate and surrounding of pressure ulcer, what is identical in all recommendations, and according to local recommendations, the recording is supplemented by an assessment of pressure ulcer boundary, tunneling, sinuses, pressure ulcer volume, margins, skin color, temperature/inflammation, odor, pain, and skin turgor. In Slovakia, documentation is monitored as part of the review activity (Journal of the Ministry of Health SR, 2004b) and in addition to the actual assessment and treatment of pressure ulcer, it also monitors its compliance with the reported nursing care to the health insurance company.

\section{Conflict of interests}

The authors have no conflict of interests to declare.

\section{Ethical aspects of the work}

The ethical aspects of resource citation have been followed. The authors declare that ethical aspects have been followed when processing the results.

\section{Problematika dokumentovania dekubitov: literárny prehl'ad}

\section{Súhrn}

Ciel': Vyhl'adat', analyzovat' a porovnat' klinické odporúčané postupy, národné odporúčania, smernice, ošetrovatel'ské štandardy a hodnotiace nástroje so zameraním na dokumentovanie dekubitov.

Metodika: Výber relevantných zdrojov sa realizoval v priebehu roka 2018 s využitím rešeršných služieb a zo zdrojov v elektronických databázach Medline, ProQuest, PubMed, knižných publikácií, zo stránok odborných spoločností a odborných časopisov. Zo 139 zdrojov bolo vybraných 38 zdrojov, ktoré boli spracované v troch fázach na základe stanovených zarad'ujúcich a vyrad'ujúcich kritérií.

Výsledky: Analýzou a porovnaním klinicky odporúčaných postupov, národných odporúčaní, smerníc, ošetrovatel'ských štandardov a hodnotiacich nástrojov so zameraním na dokumentovanie dekubitov sme zistili, že pri posudzovaní dekubitov sa najčastejšie opakuje požiadavka na dokumentovanie: stupňa dekubitu, jeho lokalizácie, vel'kosti, spodiny, exsudátu a okolia. Najviac sledovaných položiek, ktoré nám hovoria o dokumentovaní priebehu hojenia dekubitov sa nachádza v smerniciach NPUAP, EPUAP, PPPIA s konsensuálnym prístupom (GRADE), HSE, AAWC a RNAO.

Záver: Dokumentovanie dekubitov je problém riešený v rámci národných i medzinárodných odporúčaní, smerníc alebo guidelinov. Z ich analýzy a porovnania vyplynulo niekol'ko celosvetovo jednotných požiadaviek dokumentovania, ktoré sú nevyhnutným podkladom k multidisciplinárnej spolupráci a rozhodovaní o d’alšom postupe liečby.

Kl'účové slová: hodnotiace nástroje pre klasifikáciu dekubitov; národné smernice dokumentovania dekubitov; posudzovanie a dokumentovanie dekubitov

\section{References}

1. AAWC - Association for the Advancement of Wound Care (2010). Guideline of pressure ulcer guidelines. [online] [cit. 2018-10-13]. Available from: https:// s3.amazonaws.com/aawc-new/memberclicks/ AAWCPressureUlcerGuidelineofGuidelinesAug11.pdf

2. Act No. 581/2004. [Zákon č. 581/2004 Z. z., o zdravotných poistovniach, dohl'ade nad zdravotnou starostlivostou a o zmene a doplnení niektorých zákonov. In: Zbierka zákonov Slovenskej republiky, čiastka 246/2004].

3. AHRQ - Agency for Healthcare Research and Quality (2017). On-time pressure ulcer assessment. [online] [cit. 2018-10-13] Available from: http://www.ahrq.gov/professionals/systems/ long-term-care/resources/ontime/pruhealing/pruhealingassessment.html

4. AWMA - Wounds Australia (2016). Standards for wound prevention and management. 3rd edition. Osborne Park, WA: Cambridge Media.
5. Baharestani M, Black J, Carville K, Clark M, Cuddigan J, Dealey C, et al. (2009). International guidelines. Pressure ulcer prevention: prevalence and incidence in context. A consensus document. London: Medical Education Partnership (MEP) Ltd.

6. Bates-Jensen B (2001). Bates-Jensen wound assessment tool. [online] [cit. 2018-02-19]. Available from: http://wwwoundcare. ca/Uploads/ContentDocuments/BWAT.pdf

7. Black J, Baharestani MM, Cuddigan J, Dorner B, Edsberg L, Langemo D, et al. (2007). National pressure ulcer advisory panel's updated pressure ulcer staging system. Dermatol Nurs 19(4): 343-349.

8. Daniel (2015). Historie a současnost klasifikace dekubitů. Klasifikace dekubitů podle Daniela. In: Koutná M, Ulrych U, et al. (Eds). Manuál hojení ran v intenzivní péči. Praha: Galén.

9. Dehghan D, Dehghan M, Sheikhrabori S (2015). The quality of clinical documentation of patients admitted to an iranian teaching hospital: a two-year impact of clinical governance. AJNER 5(2): 159-166. DOI: 10.5958/2349-2996.2015.00033.6.

10. Dowsett C, Newton H (2005). Wound bed preparation: TIME in practice. Wounds UK 1(3): 58-70. 
11. Dowsett C, Protz K, Drouard M, Harding KG (2018). Triangle of wound assessment. Wounds Asia. [online] [cit. 2018-1023]. Available from: https://www.woundsasia.com/resources/ details/triangle-wound-assessment

12. EWMA - European Wound Management Association (2019). [online] [cit. 2018-09-18]. Available from: http://ewma.org/

13. Gray D, White R, Cooper P, Kingsley A (2010). Applied Wound Management and using the Wound Healing Continuum in Practice. Wound Essentials 5: 131-139.

14. Gunningberg M, Dahm MF, Ehrenberg A (2008). Accuracy in the recording of pressure ulcers and prevention after implementing an electronic health record in hospital care. Qual Saf Health Care 17(4): 281-285. DOI: 10.1136/qshc.2007.03341.

15. Hibbsová $P$ (2009). Metodika hodnocení stupně postižení tkáně u dekubitů. Škála stupně postižení tkání u dekubitů dle Hibbsové. In: Věstník MZ CR. Metodické doporučení. Metodika prevalenčného sledování dekubitů na národní úrovni. Částka 6: 69-82.

16. Høgsnes L, Danielson E, Norbergh KG, Melin-Johansson C (2016). Healthcare professionals' documentation in nursing homes when caring for patients with dementia in end of life a retrospective records review. J Clin Nurs 25(11-12): 16631673.

17. HSE - Health Service Executive (2018). HSE National wound management guidelines. Dublin: The Office of Nursing and Midwifery Services Director.

18. Jarošová D, Sikorová L, Marečková J, Pajorová H (2012) Elektronická dokumentace pro ošetřovatelskou diagnostiku v domácí péči. Praktický lékař 92(2): 105-107.

19. Journal of the Ministry of Health of the Czech Republic (2009). [Věstník MZ ČR] Metodické doporučení. Metodika prevalenčního sledování dekubitů na národní úrovni. Částka 6: 69-82.

20. Journal of the Ministry of Health of the Slovak Republic (2004a). [Vestník MZ SR] Odborné usmernenie MZ SR č. 22701/2004-00, ktorým sa mení a dopíňa odborné usmernenie MZ SR pre tvorbu, implementáciu a hodnotenie štandardov v ošetrovatel'stve a pôrodnej asistencii z 30. augusta 2004 č. 16138-2/2004-OO.

21. Journal of the Ministry of Health of the Slovak Republic (2004b). [Vestník MZ SR] Koncepcia odboru Revízne ošetrovatel'stvo č. 14100/2006 - OZSO. Vol. 54, čiastka 1-5.

22. Journal of the Ministry of Health of the Slovak Republic (2000). [Vestník MZ SR] Odborné usmernenie MZ SR č. SZS-1373/2000 pre poskytovanie zdravotnej starostlivosti v Agentúrach domácej ošetrovatel'skej starostlivosti. Vol. 48, čiastka 35-56.

23. Journal of the Ministry of Health of the Slovak Republic (2009). [Vestník MZ SR] Odborné usmernenie MZ SR č. 07594/2009OZS o vedení zdravotnej dokumentácie. Vol. 57, čiastka 42-48.

24. Knighton (2015). Historie a současnost klasifikace dekubitů. Klasifikace chronických ran podle Knightona. In: Koutná M, Ulrych U, et al. (Eds). Manuál hojení ran v intenzivní péči. Praha: Galén.

25. Melter $C$ (2017). Pressure ulcer prevention and treatment assessment, wound care, and healing. Wild Iris Medical Education. [online] [cit. 2018-10-28]. Available from: https:// wildirismedicaleducation.com/courses/pressure-ulcerassessment-treatment-ceu
26. NHS - National Health Service (2009). Prevention and management of pressure ulcers. [online] [cit. 2018-10-28]. Available from: http://nhs.stopthepressure.co.uk/path/docs/ Prevention\%20and\%20management\%20of\%20pressure\%20 ulcers\%20v5\%20DRAFT.pdf

27. NICE - National Institute for Health and Care Excellence (2014). Pressure ulcers: prevention and management. [online] [cit. 2018-09-13]. Available from: https://www.nice.org.uk/ guidance/cg179/chapter/recommendations\#healthcareprofessional-training-and-education

28. Nichols E (2015). Wound assessment part 1: how to measure a wound. Wound Essentials 10(2): 51-55.

29. NPUAP - National Pressure Ulcer Advisory Panel, EPUAP European Pressure Ulcer Advisory Panel and PPPIA - Pan Pacific Pressure Injury Alliance (2014). Prevention and treatment of pressure ulcers: quick reference guide. Haesler E (Ed.). Perth: Cambridge Media.

30. Nursing and Midwifery Council (2015). The Code. Profesional standards of practice and behaviour for nurses and midwives. [online] [cit. 2018-09-18]. Available from: https://www.nmc. org.uk/globalassets/sitedocuments/nmc-publications/nmccode.pdf

31. OECD - The Organisation for Economic Co-operation and Development (2019). [online] [cit. 2018-09-13]. Available from: http://www.oecd.org/

32. Pokorná A, Jarkovský J, Mužík J, Vasmanská S, Saibertová S, Krejčiř́íková P (2016). A new online software tool for pressure ulcer monitoring as an educational instrument for unified nursing assessment in clinical settings. Mefanet J 4(1): 26-32.

33. RNAO - Registered Nurses' Association of Ontario (2018). Educational Workshop for RNs and RPNs: Assessment and Management of Pressure Ulcers [online] [cit. 2018-09-13]. Available from: https://rnao.ca/sites/rnao-ca/files/Assessment_ and_Management_of_Pressure_Ulcers_-_Part_A.pdf

34. Seiler (2015). Historie a současnost klasifikace dekubitů. Klasifikace dekubitů podle Seilera. In: Koutná M, Ulrych U, et al. (Eds). Manuál hojení ran v intenzivní péči. Praha: Galén.

35. Shea JD (1975). Pressure sores: classification and management. Clin Orthop Relat Res 112: 89-100.

36. Stausberg J, Kiefer E (2009). Classification of pressure ulcers: a systematic literature review. Stud Health Technol Informa 146: 511-515. DOI: 10.3233/978-1-60750-024-7-511.

37. Stryja J, et al. (2011). Repetitorium hojení ran 2. Semily: GEUM

38. Torrance G (2015). Historie a současnost klasifikace dekubitů. Klasifikace dekubitů podle Torrance. In: Koutná M, Ulrych U, et al. (Eds). Manuál hojení ran v intenzivní péči. Praha: Galén.

39. Vainiomäki S, Kuusela M, Vainiomäki P, Rautava P (2008). The quality of electronic patient records in Finnish primary healthcare needs to be improved. Scand J Prim Health Care 26(2): 117-122. DOI: 10.1080/02813430701868806.

40. W.H.A.T. - Wound Healing Analyzing Tool (2013). [online] [cit. 2018-02-18]. Available from: http://www.what-world.com/ index.html

41. Wang N, Yu P, Hailey D, Oxlade D (2011). Developing measurements of quality of electronic versus paper-based nursing documentation in Australian aged care homes. eJHI 6(1): e7. 